\title{
GYÖRGY MARTIN'S PLACE IN APPLIED ETHNOCHOREOLOGY
}

\author{
Colin Quigley \\ Irish World Academy of Music and Dance, University of Limerick \\ E-mail: colin.quigley@ul.ie
}

\begin{abstract}
Apart from a few key works on dance structure, improvisation and Central European traditional dance, the breadth and depth of Martin's work remains inaccessible to the English reading audience and little known in dance studies. One such unacknowledged area of significant contribution is his important work in applied ethnochoreology through key interventions in Hungarian presentational stage choreography and participatory social dance revival. In both spheres Martin made a significant contribution at key moments in their development. At least two fundamental concepts drawn from his theoretical work informed his activist interventions. First, that folk dancing needs to be conceptualized, and studied, as a process (táncfolyamat). Second, that this process cannot be excised from its complete contextualization in the lives and history of its practitioners if it is to be fully understood. This theorization of dance is relevant far beyond the village dance idiom that so absorbed him. It should be more widely known, acknowledged and, indeed, applied specifically within ethnochoreology as well as dance studies in general today. As work in the application of scholarly knowledge outside the walls of academia becomes ever more important in our field, it is worth remembering that this is not an activity without precedent. Martin's theoretically informed interventions in both participatory and presentational dance practices in Hungary provide an excellent model for such work.

Keywords: traditional dance, applied ethnomusicology, applied ethnochoreology, participatory dance revival, presentational choreographic representation, applied ethnochoreology, György Martin, Ernő Pesovár, theory and practice
\end{abstract}

Hungarian ethnochoreologist György Martin (d. 1985), while celebrated in his own country, remains unknown in dance studies generally. Even in the specialist domain of dance anthropology and dance ethnology, the full extent of his work, the range of his interests, and importance of his contributions are under-appreciated. His most cited work - and usually his only work to be cited in English language literature - is the theoretical exposition of "A Structural Analysis of the Hungarian Folk Dance (A Methodological Sketch)", written with Ernő Pesovár in 1961. Google Scholar, for example, lists 21 cites for this essay, far more than any other of his English language essays, each of which are 
cited only once or twice (Google Scholar accessed on June 1, 2013). These other works are concerned with dance studies in Central Europe, and thus of more limited interest.

The vast bulk of his published work is in Hungarian language journals and therefore not as accessible to a wide international audience. Two major publications have appeared posthumously thanks to the dedication of his successors at the folk dance department of the MTA Zenetudomány Intézet: one a comprehensive study of a single dancer's dance knowledge, ${ }^{1}$ the other a comprehensive study of the music of the Gypsy stick dance ${ }^{2}$ together giving a better sense of the larger vision of dance research that remained unfulfilled after his untimely death. As with many of the more recent Hungarian publications in ethnochoreology and ethnomusicology, English language abstracts are included in a gesture to a more international audience and offer some access for the non-Hungarian speaker. However, these works are still little known outside the circle of European ethnomusicologists. Unfortunately, the discipline lacks translations of his many essays, in which the full scope of his work/contribution would be better represented.

On the occasion of this anniversary publication, I take the opportunity to draw attention to one area of significant contribution in more detail than has previously been acknowledged in English. This is his important work in applied ethnochoreology through key interventions in Hungarian presentational stage choreography and participatory social dance revival. In both spheres Martin made a significant contribution at key moments in their development. Martin's Hungarian colleagues and successors have appreciatively acknowledged this role in increasingly numerous commentaries, reminiscences, and historical accounts of the dance house movement's early years. ${ }^{3}$ An excellent source of published work on this topic, in addition to these more substantial treatments of dance house history but not much used in the critical literature on his work, are the numerous and varied short articles, opinion pieces, and interviews that have appeared in folkMAGazin since its founding in 1994. Addressing itself to all with an interest in Hungarian heritage as a forum for sharing information and expressing opinion, ${ }^{4}$ this publication is popular in tone, allowing for freer, more immediate, and less disciplined accounts that are best used as primary sources taking us further back in time and closer to the actual events. Perhaps somewhat surprisingly, Martin's own first-hand writings in this area have not been closely examined. A more theorized account of his work in applied ethnochoreolgy is lacking. In this short essay I will briefly review and comment on Martin's applied work in several categories, not unlike those identified by the American ethnomusicologist Daniel Sheehy: disseminating knowledge, providing access, developing new frames for performance, offering informed feedback, developing broad structural solutions to broad problems. ${ }^{5}$

Much of Martin's published work might be considered applied in the sense that it disseminated knowledge, albeit to a small academic specialty. In addition to Martin's large body of explicitly academic publications in scientific journals, monographs, and books, however, there are significant examples of essays aimed at a popular audience (see the

\footnotetext{
${ }^{1}$ Martin 2002.

${ }^{2}$ Martin 2004.

${ }^{3}$ See Halmos - Hoppál - Halák 2012; Sebő 2007; Siklós 2006; AbKarovits 2002.

${ }^{4}$ BANKÓ 1994.

${ }^{5}$ SHEEHy 1992: 330-331.
} 
bibliograhy below). There is room here only to mention that such publications include commentaries on festivals of folk dance, introductions to festival program books, descriptions of the scientific program and growing collection of Hungarian folkdance, and their dissemination to a general public. Many other publications are aimed at a more specialist audience of activists: dancers, musicians, teachers, and group leaders. I would draw attention here to essays such as those published in the Sippal Dobbal newsletter of the first years of dance house movement ${ }^{6}$ European links, Romanian-Hungarian relations. These two essays, one about the European connections of the dance house repertoire, the other about Hungarian-Romanian relations within it, are clearly aimed at debunking any incipient nationalist tendencies in the dance house movement, a major worry in its early years and one which has continued to plague the movement up to the present. Other writings directed at this audience of a more advisory nature will be examined below for the insight they offer into the principles guiding Martin's interventions.

Martin's role in providing access is perhaps the best known of his applied activities.

Almost all the retrospective sources recount, with one degree or another of detail, Martin's role in making available field recordings of traditional dance music from Transylvania to the musicians Béla Halmos and Ferenc Sebö, as well as his bringing them together with Sándor Timár and the Bartók dance ensemble in the years 1969/70. More than a few accounts of these events from all three of these key actors in the drama have appeared in interviews and memoires in the years since. Sándor Timár's contributions to folkMAGazin are of particular value for the glimpse they give us of his working relationship with Martin.

Timár and Martin first met in 1949 "mint regöscserkés" as youths at a scout-camp that incorporated folk dancing taught by Molnár István, the grandmaster of Hungarian dance choreography from whom both of them learned and took inspiration. These three men continued to work together in various ways throughout the decade of the $1950 \mathrm{~s}^{7}$ In its latter years, Martin and colleagues in ethnography began their field-collecting work. In 1955 Martin moved decisively toward his focus on scientific research work and the founding of the Népmüvelési Intézet Néprajzi Osztálya [later becoming MTA Népzene Kutatócsoport director], while Timár went on to the practical work of choreography and technical training within performing ensembles. Timár writes that at this crucial juncture as the two of them moved on from their work with Molnár, Martin suggested that Timár occupy himself with dance teaching and choreography, while Martin would direct his energy primarily to dance analysis and publishing his findings. ${ }^{8}$ [All translations and paraphrasings are my own].

It would transpire that this division of labor facilitated the collaborative relationship through which folkdance research and folkdance practice were able to so thoroughly inform one another. Martin, Timár writes, continued to pay close attention to his work with the Bartók Béla Táncegyüttes (established in 1958). Martin collected and Timár adapted dance material, first from Mezöség and then crucially from Szék. The events of 1968-69,

\footnotetext{
${ }^{6}$ Martin 1974, 1977.

7 Timár 2003.

${ }^{8}$ TimÁr 2003: 45.
} 
when Timár brought villagers from Szék whom he met on the streets of Budapest to rehearsals and Martin brought Sebö and Halmos to play for these, is an oft-told tale. The creative energy released by the combination of spontaneous music and dance was a revelation. For Timár, the innovation of this coming together produced new possibilities for his pedagogical work. The musicians also liked the idea and they undertook to work with the ensemble. ${ }^{9}$ Elsewhere, in an interview, Timár explains that the decision to leave István Molnár to establish his own ensemble in which he could pursue "his research, his teaching method, his choreography" strengthened the emphasis he placed on dancing together with Martin, who absorbed himself in ethnographic work in the field. Martin supported Timár's decision to direct the Bartók ensemble, since he could then pursue their project collaboratively, he working theoretically, Timár practically, to jointly strengthen the work. ${ }^{10}$

Martin's role as advisor and critic to those who worked fully in the applied domain is also acknowledged, but it is important to highlight that the degree to which the direction he sought to give to the movement was firmly based on his theoretically informed understanding of traditional dance practice. I have noted elsewhere that Martin's 'scientifically based' understanding of and appreciation for the village dance aesthetic was instrumental in setting and keeping the dance house movement "on course"11, as Béla Halmos expressed it to me in an interview (Budapest 2012), a conclusion confirmed for me by Sebö's observation that the shift to a scientific perspective from an artistic one made the dance house movement distinctive. ${ }^{12}$ But this is also true for the development of Hungarian folk dance choreography, as is made clear in this account of Martin's intervention at the crucial juncture in the revivals, both presentational and participatory, when new methods of transmission through organized teaching and explicit pedagogy required replacement of traditional modes of transmitting dance knowledge and skill in the village setting. Timár went on to develop his approach to dance pedagogy, the so-called Timár módszer that emphasizes building improvisatory competence on the model of learning a 'native language,' a method that informed dance teaching in the dance house movement as well. ${ }^{13}$

Martin's 1963 essay, “A néptánc megismertetésének célja és módszere a táncpedagógusok képzésében" [The Aim and Method of Acquainting Dance Teachers with Folk Dance] articulates the arguments he was no doubt making to Timár and other choreographers and dance teachers working with ensembles at the time, as well as sounding several important themes that recur in his later work with the dance house movement leaders. The concept of eredeti néptáncok (original folk dances) is fundamental. This dancing, he argues, is far more varied and rich than any stereotypical folk dance style could ever be.

The investigation of folkdances is not a singular task - as it is often pursued - concerned with one folkdance style or even a few regional styles, but rather it studies its multifarious forms living alongside one another, from various historical periods and the various fashions that left their marks.

In order to capture this mulitiplicity, he argues, one must turn to film recordings made

\footnotetext{
9 Timár 2000: 45.

${ }^{10}$ HollokÖI 2000: 4.

${ }^{11}$ Quigley 2013.

${ }^{12}$ SEBÖ 2012: 77.

${ }^{13}$ Hortobágyi 2012: 108-110.
} 
in the field. These films, more than 10,000 meters of them at the time, are the source of an enormous body of movement material to be studied both scientifically by researchers and practically by dancers. But crucially, to merely take motives from these sources, while useful, remains a superficial method..$^{14}$

This method is superficial because the object of study to be understood is not the dances, it is rather the "dance process" represented in the film documents. This is the second key notion that informed Martin's work. He writes,

In the case of 'kötetlen szerkezetü táncok' - dances with unregulated form (that is improvisatory and not strictly established) - we can only find insight from the film documentation, which is capturing the moment and through this we can draw some general consequences about dance-structuring methods. Showing a material, which is rich in variations, can result in finding the stable reoccurring elements of a constantly changing dance form.

The best way to approach the general theoretical consequences is to study the original folk dance recordings. Through this method the other parts of the dance art can also be given their proper place. ${ }^{15}$

He argues that the complex analysis of the formal, functional, and musical aspects of the folk dance creates a lot of questions, for example: the formation of the essential form; the method of the creation of motives; the variation; the impact of the form developing function; the different stages of the development of structure of the dance; the connection between the dance and the music; the roles and the stages of awareness and intuition; the role of person (individum) and society in dance making.

To approach the study of eredeti néptáncok it is necessary to take a complex perspective toward its multilayered reality: not only its motive movements, but its forms, its music and its particular functions; that is the "teljes, kifejlett táncfolyamatot," the entire fullblown dance process. One must study the music, as well as the movement, and not just its direct links to the dance, but also in terms of its historical style, which feeds the repertoire of the dance type, which must itself be ascertained in terms of tempo and rhythmic accompaniment. Even more importantly though, consideration of the dance process includes its role in society, as embedded in custom, its meanings and connotations, its emotional feeling, its place in community consciousness, that is the entire meaning and signifcance of a community's dance life, táncélet. ${ }^{16}$

This holistic conception of dance process proved crucial in Martin's coming engagment with the dance house movement. His importance to the dance house movement in providing access has been noted above. Writing in folkMAGazin, Héra Éva, along with many others, has noted the importance of the legacy of systematic folk music and dance collection and analysis for the dance house movement. ${ }^{17}$ The fruits of all this labor were a great help and source for the movement's musicians, dancers, and singers to draw upon,

\footnotetext{
${ }^{14}$ Martin 1963: 55.

${ }^{15}$ Martin 1963: 53.

${ }^{16}$ Martin 1963: 56.

${ }^{17}$ HÉra 2004.
} 
once Martin had introduced it to Halmos and Sebő. It was, however, not only the production of scientific knowledge that was important in Martin's life work and Héra is more interested in drawing attention to his activities in general community education and the ways in which he gave direction to the development of folk dance movement [közmüvelödésben ... néptáncmozgalmunk fejlödésének irányt adó]. ${ }^{18}$

Martin, and his predecessors like Bartók and Kodály, held a desire to promote folk music and dance not only in the domain of science and art but also as an active part of everyday culture. This was not only an abstract concept but was pursued actively through social engagement, that is, through applied ethnochoreo- and -musicology. Héra writes that Martin taught in courses, took part in performances and in festivals. He worked with ensembles, and he was at dance house meetings. He helped "us" individually as well. He encouraged, gave expert advice, supplied literature, nurtured research work, and when necessary, she concludes, critiqued and criticized. Martin could not choose between the two domains, for him research and activism (kutatás és mozgalom) made up an organic whole.

In A férfitáncok pedagógiai és táncházi alkalmazásáról [How to Use Lad's Dances in Teaching and in Dance Houses $],{ }^{19}$ Martin observes that, quite unexpectedly, ten years after founding of the urban dance house movement, the young men's dances had become a popular, indeed even indispensable, part of the entertainment. He goes on to provide information about these dances that he clearly hopes will help guide their continued practice: how they might be taught and learned, how to integrate into an evening of couple and group dances, and which of their many varieties might be most appropriate for use in this context. He does this by drawing on the underlying principles that informed his advice to presentational ensembles: that a genuine dance process is a complex whole, one glimpse of an endlessly variable and varying form of expression embedded in and emerging from villagers' lives and, implicitly throughout this essay, that dancing within urban dance houses should be based on this model, as only in that way can it succeed in its own terms as a living part of social life. If the young men's dances are to be made a part of the dance house repertoire then it follows that it is important to first grasp their variety and their place in village dance life.

To do this, Martin begins by reviewing how dancing was learned traditionally among the peasantry of the villages: separately and playfully among young boys and girls at first and then later with more active instruction received in the home, practicing what they learned among themselves in unthreatening contexts out of sight of critical eyes. There are two categories of men's dances, he notes: the open-form improvisatory solo dances and the regulated group dances. These represent two poles that together constitute a whole dance repertoire. It is important to include both in the dance houses, as each has a different focus for learning, a different pedagogical goal, and a different dance feeling to express. One is for individual self-expression, the other for expressing collectivity. In village dance life the two dance forms do not conflict but rather complete their significance together (1982: 59). In Hungarian dance the simpler, regulated collective dance form is as

\footnotetext{
${ }^{18}$ HÉra 2004: 36.

${ }^{19}$ Martin 1982.
} 
important as virtuosic solo dancing. If, in large part, it is the free men's dances that had become established in the dance houses there should be every possibility that the simpler regulated dances can also, indeed should, find acceptance and become popular. ${ }^{20}$

When describing how men's dances are used he continues to reference the village model. Before the start of a dance party the young men gather, enjoying their dancing together before the girls arrive and naturally they practice the group dances. In many places as the dance begins, first a slow celebratory dance is performed in a presentational manner, but most often the men's dances serve - szünettöl szünetig terjedö táncciklus bevezetése volt - to fill pauses between the cycles of couple dancing. The linked and solo forms appear alternately in these situations. Their second function is as a special entertainment during a pause in the merriment - néhányan a közönség szórakoztatására. The simpler dances in this case can include those of the group who might be less proficient. This practice he suggests works well in the dance house setting to perform as yet less wellknown material. Martin goes on to suggest particular men's dances for different purposes, noting the importance of a variety of men's dance repertoire for dance house leaders to know. Throughout the essay Martin emphasizes and repeatedly reiterates the need to "pay attention to the folk/peasant/village practice and norms".

In the two works quoted here Martin articulates the principles that he espoused in his applied work with presentational and participatory uses of traditional dance in modern contexts. He devoted his scientific work to analysis of the original dances (eredeti táncok) that he documented in Transylvanian villages and to an understanding of dance life in these villages. He worked generously in an applied way to help perpetuate this kind of dancing both in its places of origin and its modern transformation. It is clear from the statements I have cited above that Martin saw his theoretical work in folk dance analysis as part of a larger whole. The interventions he made into the practical world of folk dancing were essential to the character that both presentational and participatory folk dance revitalization took in the 1970s and 1980s. This direction kept the dance house movement closer to reproducing in a modern setting the aesthetic values it carried among the villagers who created the idiom.

At least two fundamental concepts drawn from his theoretical work informed his activist interventions. First, that folk dancing needs to be conceptualized, and studied, as a process (táncfolyamat). Second, that this process cannot be excised from its complete contextualization in the lives and history of its practitioners if it is to be fully understood. This theorization of dance is relevant far beyond the village dance idiom that so absorbed him. It should be more widely known, acknowledged and, indeed, applied specifically within ethnochoreology as well as dance studies in general today.

As work in the application of scholarly knowledge outside the walls of academia becomes ever more important in our field, it is worth remembering that this is not an activity without precedent. Martin's theoretically informed interventions in both participatory and presentational dance practices in Hungary provide an excellent model for such work, and his contribution in no small measure accounts for the acknowledgement the dance house method has received as a 'best practice' in the safeguarding of intangible cultural heritage

${ }^{20}$ Martin 1982: 61. 
from UNESCO ${ }^{21}$ The discussion and theorization of 'applied' work first in anthropology, then folklore studies, ethnomusicology, and most recently ethnochoreology is ongoing. As Anthony Seeger noted in "Lost Lineages and Neglected Peers: Ethnomusicologists outside Academia"22, part of a growing literature on applied ethnomusicology, "omitting from the history of our discipline [those] who worked outside the universities ... is ultimately rather limiting" and just so, as in Martin's case, it is an unfortunate elision to exclude a particular scholar's work outside of academia from our purview.

\section{LITERATURE}

ABKARovits, Endre

2002: Táncházi Portrék. Budapest: Hagyományok Háza.

BANKó, András

1994: Háztáji beköszöntő. folkMAGazin 1, 4.

Halmos, Béla - Hoppál, Mihály - Halák, Emese (eds.)

2012: Meg kell a búzának érni: A magyar táncházmozgalom 40 éve. Budapest: Európai Folkór Intézet. HÉrA, Éva

2004: Martin György és a folklórmozgalom kapcsolata. folkMAGagazin 1, 36.

HoLLOKÖI

2000

HorToвÁGYI, Gyöngyvér

2012: Néptáncoktatásról régen és ma. In: Halmos, Béla - Hoppál, Mihály - HalÁk, Emese (eds.): Meg kell a búzának érni: A magyar táncházmozgalom 40 éve. Budapest: Európai Folkór Intézet, 108-110.

MAÁcz, László

1981: A magyar néptáncmozgalom a hetvenes években. In: BéRes, András - SzentPÁl, Mária (eds.): Tánctudományi Tanulmányok 1980-1981. Budapest: A Magyar Táncmüvészek Szövetsége Tudományos Tagozata, 71-105.

Martin, György

1963: A néptánc megismertetésének célja és módszere a táncpedagógusok képzésében (The Aim and Method of Acquainting Dance Teachers with Folk Dance). Táncmüvészeti Értesitö, 50-62. Reprinted 1969. In: MAÁcz, László (ed.) Szöveggyüjtemény Néptáncpedagógusok Kiskönyvtára, 5-20.

1974: Az európai tánckultúrák és a tánchagyomány. Síppal Dobbal 3, 27-37.

1977: A magyar és a román táncfolklór viszonya az európai összefüggések tükrében. Síppal Dobbal 6, 24-32.

1979: Az öntevékeny táncmozgalom müvészeti útjairól (interjú). [A Contribution to the Artistic Debates on the Amateur Dance Movement (interview)]. Táncmüvészet 11(8).

1980: Táncház és színpad [Dance House and Stage]. Népszava, Február 2, 7.

1981: Az új folklórhullám és néptáncmozgalom előzményeiröl (interjú). [On the Precedents of the New Wave of Interest in Folklore and the Folk Dance Movement (interview)]. Kultúra és Közösség. 4, $42-53$.

1982: A férfitáncok pedagógiai és táncházi alkalmazásáról [How to Use Lad’s Dances in Teaching and in Dance Houses]. In: NAGY, Judit (ed.): Zene, tánc . . Zene-és táncosztály módszertani kiadványa. Budapest: Népművelési intézet, 56-67.

2002: A botoló tánc zenéje. Budapest: MTA Zenetudományi Intézet - Hagyományok Háza.

2004: Mátyás István Mundruc: Egy kalotaszegi táncos egyéniségvizsgálata. Budapest: Planétás.

\footnotetext{
${ }^{21}$ UNESCO 2011.

${ }^{22}$ SeEger 2006.
} 
Martin, György - Pesovár, Ernő

1961: A structural analysis of the Hungarian folk dance (A methodological sketch). Acta Ethnographica $10,1-40$.

Quigley, Colin

2012: Táncház revival és a vonós zenekarok muzsikája Közép-Erdélyben. In: Halmos, Béla - HoppÁL, Mihály - HaLÁк, Emese (eds.): Meg kell a búzának érni: A magyar táncházmozgalom 40 éve. Budapest: Európai Folkór Intézet, 82-88.

2013: The Hungarian Dance House Movement and Revival of Transylvanian String Band Music. In: BitHELL, Caroline - HiLl, Juniper (eds.): The Handbook of Music Revivals. Oxford: Oxford University Press. SeBö, Ferenc

2007: A táncház sajtója: Válogatás a korai évekböl 1968-1992. Budapest: Hagyományok Háza, Timp Kiadó.

2012: Táncház és tudomány. In: Halmos, Béla - Hoppál, Mihály - Halák, Emese (eds.): Meg kell a búzának érni: A magyar táncházmozgalom 40 éve. Budapest: Európai Folkór Intézet, 82-88.

SEEgER, Anthony:

2006: Lost Lineages and Neglected Peers: Ethnomusicologists outside Academia. Ethnomusicology 50(2), 214-235.

SHeEHy, Daniel J.

1992: A Few Notions about Philosophy and Strategy in Applied Ethnomusicology. Ethnomusicology 36(3), Special Issue: Music and the Public Interest, 323-336.

SiKLÓs, László

2006: Táncház. Budapest: Hagyományok Háza and Timp Kiadó.

TIMÁR, Sándor

2003: Martin Györgyre emlékezve. folkMAGazin 4, 44-45. Available online: http://folkmagazin.hu/ flipbook/index.php?file=mag03_4

UNESCO

2011: Táncház Method: A Hungarian Model for the Transmission of Intangible Cultural Heritage. Available online: http://www.unesco.org/culture/ich/en/Art18/00515. (Acessed on: 09/23/2012)

\section{ADDITIONAL SELECTED BIBLIOGRAPHY OF MARTIN'S POPULAR WRITINGS}

1977a: A Hagyományőrző Népi Együttesek veresegyházi fesztiválja [Festival of Traditionalist Folk Ensembles at Veresegyház] (értékelés). 6-12.

1977b: Duna menti népek dalai, táncai [Songs and Dances of Peoples along Danube]. Esti Muzsika. Az Országos Filharmónia Müsorfüzete 11-12.

1978a: A falusi Hagyományőrző Együttesek új műveinek bemutatója [A Show of the New Composition of Traditionalist Ensembles of Villages] (comments). Veresegyház, 5-11.

1978b: A VI. Duna menti Folklórfesztivál elé [Before the 6th Folklore Festival of Peoples along Danube] (preface of the programm). Kecskemét, 15-20.

1979a: A Duna menti Folklórfesztiválról 1968-1978 [On the Folklore Festival of the Peoples along Danube]. Ethnographia XC, 256-258.

1979b: Javaslatok az oktatási és tudományos szakbizottság munkájához [Proposals for the Work of the Commission of Science and Education]. In: A néptáncmozgalom néhány alapvetö kérdéséröl 4047.

1979c: Az öntevékeny táncmozgalom müvészeti útjairól (interjú) [A Contribution to the Artistic Debates on the Amateur Dance Movement] (interview). Táncmüvészet 11(8).

1979d: A Hagyományőrző Népi Együttesek veresegyházi találkozója [The Festival of Traditionalist Folk Ensembles at Veresegyház] (comments). Veresegyház 1978, A népi együttesi mozgalom problémái 3-10., Budapest, 17-23. 
1981: Az új folklórhullám és néptáncmozgalom előzményeiről (interjú) [On the Precedents of the New Wave of Interest in Folklore and the Folk Dance Movement (interview)]. Kultúra és Közösség 4, 42-53.

1982: A Hagyományőrző Népi Együttesek országos találkozója Veresegyház 1981 [The National Festival of Traditionalist Folk Ensembles] (comments). Budapest fesztivál 1982 [Festival of Traditionalist Ensembles] (comments) In: 7 év a Hagyományőrző Népi Együttesek életéből 44-74. 